\title{
An HPLC method for determining desirable or undesirable conjugated linoleic acid
}

\author{
M. Czauderna ${ }^{1}$, J. Kowalczyk', A. Potkański², M. Szumacher-Strabel ${ }^{2}$ \\ and $G$. Chojecki ${ }^{1}$
}

\author{
'The Kielanowski Institute of Animal Physiology and Nutrition, \\ Polish Academy of Sciences \\ 05-110 Jablonna, Poland \\ 'Department of Animal Nutrition and Feed Management, \\ August Cieszkowski Agricultural University \\ Wolyniska 33, 60-637 Poznań. Poland
}

\begin{abstract}
A binary gradient elution system with photodiode array detection at $234.5 \mathrm{~nm}$ was used for analysis of underivatized conjugated linoleic acid (CLA). The CLA isomers were substantially retained on the columns and were distinct from saturated, unsaturated non-conjugated fatty acids, background fluctuations and endogenous substances in milk and intestinal digesta samples. All CLA isomers appeared as a pair of large peaks at $14.1 \pm 0.1$ and $14.6 \pm 0.1$ min of elution, respectively. Trace amounts of other unidentified conjugated dienes in these biological samples were detected after $18 \mathrm{~min}$ of elution. All endogenous substances in milk, meat and intestinal digesta samples are transparent in the applied UV monitoring range $(234 \pm 2 \mathrm{~nm})$. Elimination of pre-column derivatization yields a less expensive, more specific and simpler analytical tool for routine determination of conjugated dienes in milk, meat and intestinal digesta.
\end{abstract}

KEY WORDS: conjugated linoleic acid, milk, duodenal digesta, determination, HPLC

\section{INTRODUCTION}

Feed ingested by ruminants is subjected to microbial attack in the rumen. Complex plant lipids are hydrolyzed rapidly and polyunsaturated fatty acids, consisting mainly of linolenate, undergo extensive hydrogenation and double bond migration to yield a mixture of geometrical (cis, trans) and positional (9-11,9-13) isomers of 
linoleic acid (C1 18:2 n-6; i.e., CLA) (Chouinard et al., 1999; Ostrowska et al., 1999; Mir et al., 2000). Cis-9 trans- 11 linoleic acid is the major isomer of the CLA mixture (Jahreis et al., 1997; Mir et al., 2000). The amount and type of feed can influence the microbial population of the rumen and this can influence hydrogenation and formation of trans isomers of milk fat (MF). In western countries the contribution of milk products to total trans fatty acid ( $t$-FAs) intake is estimated as $6-25 \%$ (Henninger et al., 1994). The $t$-FA content in food is also an indication of the degradation of naturally occurring unsaturated fatty acids in plants during commercial hydrogenation (Heinig et al., 1998). Due to the function of fatty acids (FAs) as carriers of fat-soluble vitamins, components of nerve cells, membranes, hormones, and biliary acids they are of great importance for living organisms (Heinig et al., 1998). In fact, recent studies have shown that $t$-FAs have, in general, a negative impact on lipoprotein metabolism (Heinninger et al., 1994). Unexpectedly, certain $t$-FAs as CLA (mainly cis-9 trans- $/ 1$ linoleic acid) are recognized as having antioxidative and anticarcinogenic properties (Ostrowska et aI., 1999; Mir et al., 2000). Moreover, CLA has been shown to stimulate immune responses and protect against arteriosclerosis (Mir et al., 1999). Therefore, studies on methods of accurately determining the CLA content in milk, meat and digesta and differentiating CLA from saturated and unsaturated FAs with emphasis on $t$-Fas, were undertaken.

\section{MATERIAL AND METHODS}

Reagents

All chemicals were of analytical grade; acetonitrile, water and methanol were of HPLC grade. Triethylamine and 2,4-dibromoacetophenone were from Merck. Palmitic, stearic acids, CLA and all other cis and/or trans fatty acids were purchased from Sigma. An internal standard (nonanoic acid) and other saturated fatty acids were from Fluka. All other chemical reagents were from POCH (Gliwice, Poland). The mobile phases were filtered through a $0.45 \mu \mathrm{m}$ membrane (Millipore) and then degassed for 2-3 min in vacuum with ultrasonication prior to use.

\section{Chromatographic equipment}

The instrument used consisted of a Water 625LC system, which included a controller for gradient elution, two Waters 501 pumps and a Water 515 pump. The apparatus is coupled to a Waters 717plus WISP autosampler and a Waters 996 photodiode array detector. Data acquisition was performed on an Optimus Pentium 5P60 computer with Millennium 2001 software. Separations were performed 
on two Nova Pak $\mathrm{C}_{18}$ columns ( $4 \mu \mathrm{m}, 250 \times 4.6 \mathrm{~mm}$ I.D., Waters) in conjunction with a Waters guard $C_{18}$ column of $10 \times 6 \mathrm{~mm}$ I.D. Two HPLC grade solvents were used; solvent A was acetonitrile, while solvent B was water. A binary gradient elution system with UV detection at $234.5 \mathrm{~nm}$ (Table 1) was used for analysis of underivatized CLA in milk, meat and intestinal digesta samples.

TABLE 1 Binary gradient elution system used for direct analysis of underivatized CLA (columns temperature $32^{\circ} \mathrm{C}$ )

\begin{tabular}{ccccc}
\hline \multirow{2}{*}{$\begin{array}{c}\text { Fime } \\
\min \end{array}$} & $\begin{array}{c}\text { Flow rate } \\
\text { ml/min }\end{array}$ & solvent A & solvent B & Curve \\
\hline 0 & 2.0 & 55.0 & 45.0 & \\
\hline 11.0 & 2.0 & 98.0 & 2.0 & 6 \\
15.2 & 2.0 & 100.0 & 0 & 6 \\
23.0 & 2.3 & 100.0 & 0 & 6 \\
23.2 & 2.2 & 55.0 & 45.0 & 6 \\
30.0 & 2.0 & 55.0 & 45.0 & 11 \\
\hline
\end{tabular}

\section{Preparation and hydrolysis of biological samples}

Milk, meat and duodenal digesta samples were collected from sheep. All samples were frozen, lyophilized, and the obtained residues were stored in sealed tubes at $-20^{\circ} \mathrm{C}$ until analyzed. Milk ( $\left.\sim 50 \mathrm{mg}\right)$ and duodenal digesta samples $(\sim 105 \mathrm{mg})$ were hydrolyzed with $4 \mathrm{ml}$ of $2 \mathrm{M} \mathrm{NaOH}$ at $\sim 85^{\circ} \mathrm{C}$ for $35 \mathrm{~min}$ and then the hydrolyzed samples were acidified with $4 \mathrm{M} \mathrm{HCl}$ to $\mathrm{pH} \sim 2$. The free fatty acids were extracted four times with $3 \mathrm{ml}$ of dichloromethane. The organic layer was removed under a gentle stream of argon and the residue dissolved in $1 \mathrm{ml}$ of acetonitrile. The obtained CLA solutions were injected onto HPLC columns. Undecanoic acid (an internal standard) and other saturated and unsaturated non-conjugated fatty acids were assayed after pre-column derivatization (Czauderna and Kowalczyk, 2001).

\section{RESULTS AND DISCUSSION}

Larger quantities of CLA are found in animal sources than in vegetable sources, particularly in products of ruminant origin such as dairy products. Therefore, the subject of the presented work was to study the CLA content in milk, meat and intestinal digesta. In fact, ruminal and duodenal fatty acid compositions signifi- 
cantly influence the essential fatty acid profile of milk, red meat, etc. CLA represents a mixture of geometric and positional isomers of C18:2 n-6. Presently, we know of seventeen CLA isomers (Ha et al., 1989), however, cis, trans/trans, cis$8,10-;-9,11 ;-10,12-;$ and $-11,13$-octadecadienoic acid accounts for only the main isomers. Considering the above, it is essential to use improved methods for routine quantification of conjugated dienes with emphasis on CLA in milk and intestinal digesta samples. As shown in Figure 1, in our HPLC system (Table 1) the underivatized CLA isomers were substantially retained on two $\mathrm{C}_{18}$ columns and were completely separated from background interference and endogenous compounds in milk and duodenal digesta samples. The underivatized CLA samples eluted as pair of large peaks clearly distinct from critical di-unsaturated fatty acids (particularly linoleic and linolelaidic acids) and from all unidentified endogenous species in milk and intestinal digesta by using unique UV monitoring at $234.5 \mathrm{~nm}$. Indeed, the underivatized conjugated dienes showed a very high band in the spectral range from 210 to $250 \mathrm{~nm}$ due to the presence of conjugated double bonds. As can be seen from chromatographic runs of milk, duodenal digesta and a standard of the CLA isomers, the procedure resulted in reproducible separation of two CLA peaks, which eluted at $14.1 \pm 0.1$ and $14.6 \pm 0.1 \mathrm{~min}$, respectively. Moreover, we found that trace quantities of other unidentified conjugated dienes in milk $(\sim 1.5 \mu \mathrm{g} / \mathrm{g} \mathrm{DM})$ and duodenal digesta $(\sim 0.05 \mu \mathrm{g} / \mathrm{g}$ DM) samples were eluted after $18 \mathrm{~min}$ of the HPLC run. It is possible that these dienes contained more than eighteen carbon atoms since the retention times of these species significantly increased with decreasing polarity, i.e., increasing alkyl chain length. As expected, all conjugated diene peaks were absent from the blank when this gradient elution system was used.

CLA, quite likely the cis/trans 10,12 isomer, has been shown to decrease milk fat secretion (Mire et al., 2000) and body fat deposition (Dudgeon et al., 1997; Dunce et al., 1998). Thus manipulation of the diet of dairy cattle may be a means of increasing the CLA content of duodenal digesta and milk of dairy cows (Table 2). Moreover, appropriate dietary supplementation can reduce the levels of saturated fatty acids of milk and meat (Best et al., 2000). Therefore, the current HPLC me-

TABLE 2

The CLA content in ovine milk and duodenal digesta samples

\begin{tabular}{lrc}
\hline $\begin{array}{l}\text { Dose of linseed } \\
\text { oil in dict, } \%\end{array}$ & $\begin{array}{c}\text { Milk } \\
\mu \mathrm{g} / \mathrm{g}^{\mathrm{a}}\end{array}$ & $\begin{array}{c}\text { Duodenal digesta } \\
\mu \mathrm{g} / \mathrm{g}^{\mathrm{i}}\end{array}$ \\
\hline Controt & 3.0 & 0.26 \\
8 & 12.4 & 0.75 \\
10 & 13.7 & 0.55 \\
\hline
\end{tabular}

a the CLA content $(\mu \mathrm{g})$ in lyophilised assayed samples 

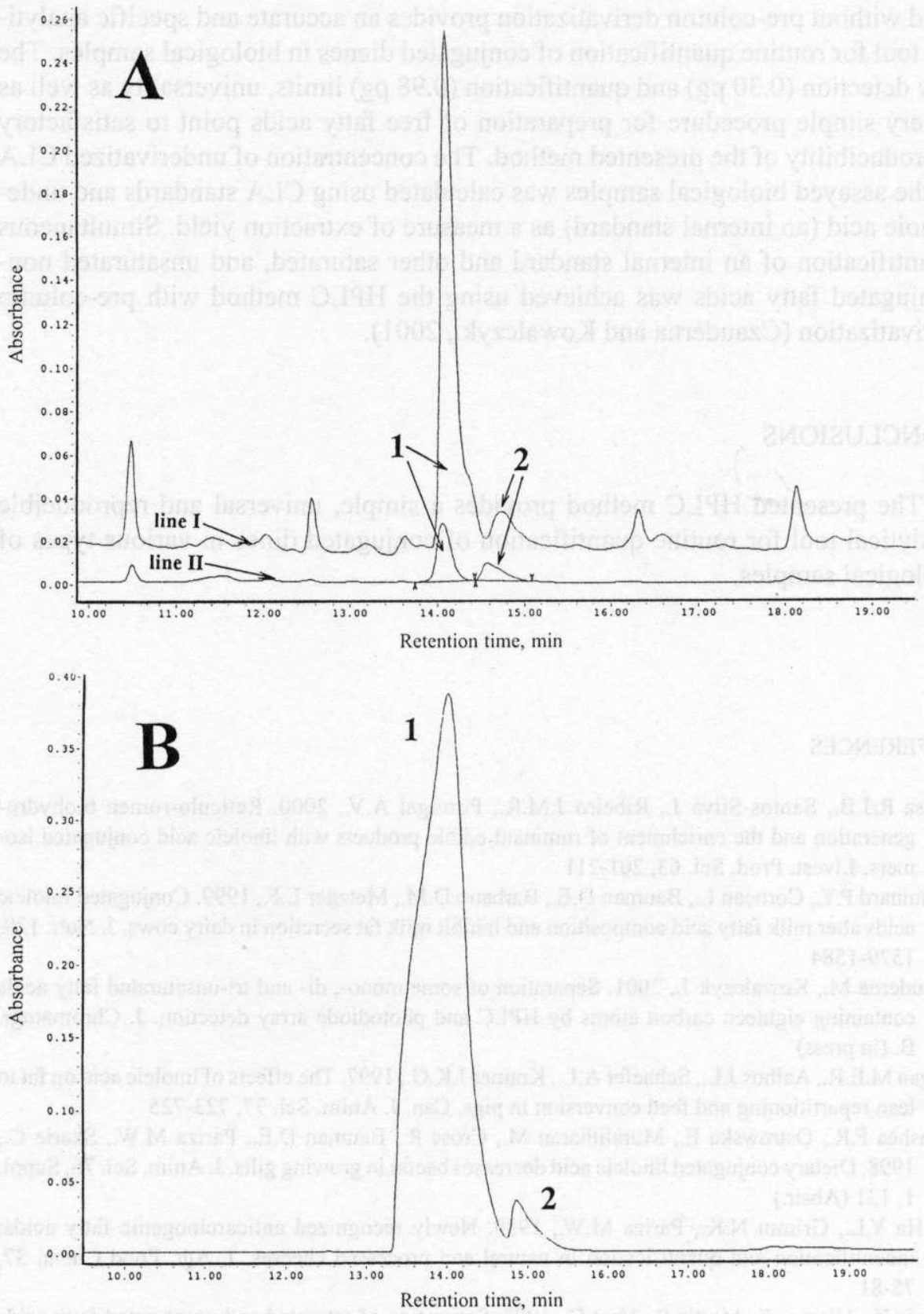

Figure 1. The part of a typical HPLC chromatogram for the underivatized CLA isomers. The analyses were performed using the binary gradient elution system with UV detection at $234.5 \mathrm{~nm}$. Peaks: 1 and 2 - the CLA isomers. Chromatogram A: line I - a milk sample (CLA content: $\sim 11.4 \mu \mathrm{g} / \mathrm{g} \mathrm{DM}$ ); line II- a duodenal digesta sample (CLA content: $\sim 0.55 \mu \mathrm{g} / \mathrm{g} \mathrm{DM}$ ). Chromatogram B: a standard of the CLA isomers 
thod without pre-column derivatization provides an accurate and specific analytical tool for routine quantification of conjugated dienes in biological samples. The low detection $(0.30 \mathrm{pg})$ and quantification $(0.98 \mathrm{pg})$ limits, universality as well as a very simple procedure for preparation of free fatty acids point to satisfactory reproducibility of the presented method. The concentration of underivatized CLA in the assayed biological samples was calculated using CLA standards and undecanoic acid (an internal standard) as a measure of extraction yield. Simultaneous quantification of an internal standard and other saturated, and unsaturated nonconjugated fatty acids was achieved using the HPLC method with pre-column derivatization (Czauderna and Kowalczyk., 2001).

\section{CONCLUSIONS}

The presented HPLC method provides a simple, universal and reproducible analytical tool for routine quantification of conjugated dines in various types of biological samples.

\section{REFERENCES}

Bessa R.J.B., Santos-Silva J., Ribciro J.M.R., Portugal A.V., 2000. Reticulo-rumen biohydrogeneration and the enrichment of ruminant edible products with tinoleic acid conjugated isomers. Livest. Prod. Sci. 63, 201-21!

Chouinard P.Y., Corneau L., Bauman D.E., Barbano D.M., Metzger L.F., 1999. Conjugated linoleic acids alter milk fatty acid composition and inhibit milk fat secretion in dairy cows. J. Nutr. 129, $1579-1584$

Czatıderna M., Kowalczyk J., 2001. Separation of some mono-, di- and tri-unsaturated fatty acids containing eighteen carbon atoms by HPLC and photodiode array detection. J. Chromatogr. B. (in press)

Dugan M.E.R., Aalhus J.L., Schaefer A.L., Kramer J.K.G., 1997. The effects of hinoleic acid on fat to lean repartitioning and feed conversion in pigs. Can. J. Anim. Sci. 77, 723-725

Dunshea F.R., Ostrowska E., Muralitharan M., Cross R., Bauman D.E., Pariza M.W., Skarie C., 1998. Dietary conjugated linoleic acid decreases bacfat in growing gilts. J. Anim. Sci. 76, Suppl. 1,131 (Abstr.)

Ha Y.L., Grimm N.K., Pariza M.W., 1989. Newly recognized anticarcinogenic fatty acids: indentification and quantification in natural and processed cheeses. J. Agr. Food Chem. 37, $75-81$

Heinig K., Hissner F., Martin S., Vogt C., 1998. Separation of saturated and unsaturated fatty acids by capilary electrophoresis and HPLC. Amer. Lab., May, 24-29

Henninger M., Ulberth F., 1994. Trans fatty acid content of bovine milk fat. Milchwissenschaft 49, $555-558$ 
Mir Z,, Goonewardene L.A., Okine E., Jaegar S., Scheer H.D., 1999. Effect of feeding canola oil on constituents, conjugated linoleic acid (CLA) and long chain fatty acids in goats milk. Small Ruminant Res. 33, 137-143

Mir Z., Ruslifeldt M.L., Mir P.S., Paterson L.J., Weselake R.J., 2000. Effect of dietary supplementation with either conjugated linoleic acid (CLA) or linoleic acid rich oil on the CLA content of lamb tissues. Small Ruminant Res. 36, 25-31

Ostrowska E., Muralitharan M., Cross R.F., Bauman D.E., Dunshea F.R., 1999. Dictary conjugated linoleic acids increase len tissue and decrease fat deposition in growing pigs. J. Nutr. 129, $2037-$ 2042

\section{STRESZCZENIE}

\section{Metoda HPLC oznaczania pożądanego lub niepożądanego sprzężonego kwasu linolowego}

Do bezpośređniego oznaczania sprzęzonego kwasu linolowego (SKL) zastosowano podwójny gradientowy system elucji i fotodiodową detekcje przy $234,5 \mathrm{~nm}$. Izomery SKL są silnie wiązane przez odwróconą fazę kolumn oraz rozdzielają się od nasyconych i nienasyconych kwasów thuszczowych, fluktuacji tła oraz substancji zawartych w mleku i treści przewodu pokarmowego. Elucja wszystkich izonerów SKL prowadziła do pojawienia się pary dużych pików o czasach retencji $14,1 \pm 0,1$ i $14,6 \pm 0,1$ min. Śladowe ilości innych niczidentyfikowanych sprzężonych dienów w próbkach biologicznych wykryto po 18 min elucji. W'szystkie endogenne substancje obecne w mleku, mięsie i treści jelit owicc nic absorbują w stosowanym zakresic UV $(234 \pm 2 \mathrm{~nm})$. Wycliminowanie przed-kolumnowej derywatyzacji sprawia, że jest to metoda tańsza, bardziej specyficzna oraz prosta, pozwalająca na rutynowe oznaczanie sprzężonych dienów w mleku, mięsie i treści przewodu pokarmowego. 